\title{
Social Capital and Educational Achievements: Coleman
} vs. Bourdieu

Silvia Rogošić ${ }^{\star 1}$ AND BRANISLAVA BARANOVIĆ ${ }^{2}$

$\approx$ The influence of social capital on an individual's educational achievements is the subject of numerous scientific papers. Research on social capital is most frequently based on Coleman's (1988) or Bourdieu's (1986) theories of capital, which are related to different paradigms of social theory: whereas Coleman's approach has its roots in structural functionalism, Bourdieu's approach contains elements of conflict theory. A number of authors, starting with Bourdieu, attempt to explain and prove that, when connected with the education of individuals, the activity of social capital facilitates social reproduction. Other authors support the notion that social capital is, in fact, a powerful weapon that encourages social mobility. A third group of researchers emphasise that neither of these approaches in isolation can entirety explain the influences of social capital on an individual's education (Ho, 2003). The present paper offers a review of research focusing on the influences of social capital on educational achievements, while outlining the fundamental differences between the two theoretical approaches that are most frequently used for research of this topic. The aim of the paper is to explain the influence of social capital on an individual's educational achievements under Bourdieu's and Coleman's theoretical concepts, and to establish whether combining the approaches is possible. The conclusion and arguments show that it is legitimate to use all three theoretical approaches.

Keywords: Coleman, Bourdieu, social capital, educational achievements, theory of social reproduction, theory of social mobility 


\section{Socialni kapital in izobraževalni dosežki: Coleman : Bourdieu}

Silvia Rogošić IN BRANISLAVA BARANOVIĆ

$\propto$ Vpliv socialnega kapitala na izobraževalne dosežke posameznikov je predmet številnih znanstvenih prispevkov. Raziskave o socialnem kapitalu najpogosteje temeljijo na Colemanovi (1988) ali Bourdieujevi (1986) teoriji kapitala, ki sta povezani z različnima paradigmama socialne teorije: Colemanov pristop ima korenine v strukturnem funkcionalizmu, Bourdieujev pristop pa vsebuje elemente konfliktne teorije. Veliko avtorjev, začenši z Bourdieujem, skuša pojasniti in dokazati, da - kadar je socialni kapital povezan z izobrazbo posameznikov - aktivnost socialnega kapitala pospešuje socialno reprodukcijo. Drugi avtorji podpirajo idejo, da je socialni kapital pravzaprav močno orožje, ki spodbuja socialno mobilnost. Tretja skupina raziskovalcev poudarja, da nobeden izmed teh pristopov sam zase ne more v celoti pojasniti vpliva socialnega kapitala na izobrazbo posameznikov (Ho, 2003). Prispevek nudi pregled raziskav, ki se osredinjajo na vpliv socialnega kapitala na izobraževalne dosežke, s tem da poudarja osnovne razlike med dvema teoretičnima pristopoma, ki sta najpogosteje uporabljena pri raziskavah na to temo. Namen prispevka je pojasniti vpliv socialnega kapitala na izobraževalne dosežke posameznikov s pomočjo Bourdieujevega in Colemanovega teoretskega koncepta in ugotoviti, ali je kombinacija pristopov mogoča. Zaključki in argumenti kažejo, da je mogoče uporabiti vse tri teoretske pristope.

Ključne besede: Coleman, Bourdieu, socialni kapital, teorija socialne reprodukcije, teorija socialne mobilnosti 


\section{Introduction}

The theory of social capital is one of the most influential and most popular theories to emerge in social sciences over the last two decades (Adler \& Kwon, 2002; Coleman, 1988; Fukuyama, 2000; Putnam, 1993; Woolcock, 1998). The popularity of the concept of social capital is a result of attempts to accentuate the value of social relations in political debates, to re-establish the normative dimension as a subject of social analyses, and to create concepts that reflect the complexity and interrelatedness of appearances in the real world (Schuller, Baron \& Field, 2000).

The theory of social capital views capital as the resources contained in social relations. Lin (1999) states that the notion of social capital has a very simple and clear meaning - investing in social relationships with expected benefits - and emphasises that this definition is in line with other definitions that have contributed to debates on social capital (Bourdieu, 1986; Coleman, 1988; Coleman, 1990; Erickson, 1996; Flap, 1994; Portes, 1998; Putnam, 1993).

One of the first authors to emphasise the relationship between life successes and various forms of capital was economist Loury (1977), who claimed that the quantity of resources we can invest in our development (i.e., level of education) depends significantly on our social background.

The concept of social capital serves to explain the influence of social position on the development of human capital (which is measured by the level of education). Social capital is researched within the framework of different approaches, thus resulting in the emergence of numerous conceptual and methodological issues: the coherence and uniqueness of concepts, its analytical validity and heuristic usefulness, operational issues with respect to issues of social confrontations and social exclusion, its political and social implications, etc. (Baron, Field \& Schuller, 200o). Some of these issues emerged among researchers who linked social capital with an individual's educational achievements (grade point averages at various school levels, grade retention, drop-out rate, enrolment in secondary school, college enrolment, graduation, duration of studies, etc.). Given that all forms of capital are actually resources that can be used to achieve various goals, the ways in which various forms of capital are related to attaining particular educational aims are also researched.

Research to date indicates that educational achievements of individuals are related to various forms of capital that an individual possess (or does not possess): social, economic and cultural capital (Coleman, 1988; 1982; Doolan, 2009; Eng, 2009; Sullivan, 2001). Individuals who have more access to these forms of capital demonstrate greater educational achievements (Pishghadam 
\& Zabihi, 2011). A large number of scientific papers emphasise, in particular, the significance of the relationship between social capital and the educational achievements of an individual (Parcel \& Dufur, 2001; Pishghadam \& Zabihi, 2011; White \& Glick, 2000). Differences in educational success can be attributed to different levels of existing social capital, which is produced in the networks and connections of families that the school serves. For instance, social capital supports educational success in the form of appropriate school climate and the values that motivate students to achieve higher goals (Acar, 2011). The student's development is strongly shaped by social capital in the school, community and family (Acar, 2011). Furthermore, social capital positively affects educational achievement and, consequently, students' behaviour and development: it reduces drop-out rates and increases graduation rates (Israel et al., 2001) and college enrolment (Yan, 1999), as well as positively affecting achievements in tests (Sun, 1999).

Research on the link between social capital and educational achievements mostly emerges from either Coleman's (1988) or Bourdieu's (1986) theoretical foundations. A number of authors base their research on interpretations and outcomes that are a combination of both of these approaches (Ho, 2003; Pishghadam \& Zabihi, 2011); however, such authors are often criticised for not taking into account the fact that the two concepts of social capital are related to entirely different paradigms of social theory (Pusztai, 2014). As such, these approaches are subject of numerous criticisms, and the question arises as to which approach to use in which situations/contexts.

The aim of the present paper is to explain the impact of social capital on the educational achievements of individuals through Bourdieu's and Coleman's theoretical frameworks, and to establish whether combining the approaches is possible. The methodology of the study is based on an analysis and comparison of existing theoretical and research findings (relying on Bourdieu's, Coleman's or a combined conceptual framework) that examine the links between social capital and educational achievement.

\section{Coleman's concept of social capital}

For Coleman (1990), social capital is a mode of social structure that eases the activity of an individual in a structured context. Whether a particular kind of social structure represents social capital, however, depends on whether its function serves the individual involved in a particular action. Coleman's analysis starts with a critique of the dominant theory of social capital in the sphere of an individual's decision-making, as, in his opinion, social capital has a stronger 
influence on an individual's education and is more evenly distributed than other types of capital in society (financial and human) (Golubović \& Golubović, 2007). The theory of rational choice, whose fundamental conceptual means is social capital, emphasises the fact that the agent acts based on rational thought, i.e., employs optimisation (Coleman \& Fararo, 1992). Optimisation is manifested in maximising the usefulness of a particular action or minimising imposition in a particular action and similar. The action is compared to its expected outcomes by the agents themselves, and it is assumed that agents will select actions that have the best outcome. The theory of rational choice views social capital as a promoter of individual action that can result in social mobility. Individuals invest in their relationships with others assuming that they will also benefit from such investments. In the end, individuals calculate and determine which actions they will take with respect to the quality and quantity of the social relationships in which they are involved.

Followers of Coleman's tradition operationalise social capital by highlighting the social capital available within the family (which implies the quality of family relationships and the family structure), as well as the social capital of the community (the quality of relationships between members of the community; in some cases, authors also take structure into consideration). At the same time, the framework of rational choice theory explains ways in which social capital promotes social mobility (Miekiewicz et al., 2011). Coleman's understanding of social capital (1988) surpasses the boundaries of individual social capital and becomes a characteristic of the community (institution, organisation). In this way, social capital can be measured on the level of educational institutions (e.g., schools, universities). This form of social capital, according to Coleman (1993), involves a network of all of the individuals who are members of particular organisations. Schaefer-McDaniel (2004), for example, state that an analysis of the social capital of a school should encompass relationships between all subjects in the school context, making social capital a characteristic of the entire organisation, whereby the power of its actions is closely related to how closed the network is. Coleman (1990) uses the term network closure in order to describe an enclosed circle of acquaintances, i.e., a network consisting of persons who know each other and interact. Obligations and expectations, exchange of information, norms and sanctions, and the relationship with authority, all of which Coleman considers aspects of the social capital of the community, are more apparent if the network is closed. The social capital of the community can be used by individuals in an attempt to achieve personal goals. However, organisational social capital does not only contribute to the achievement of personal goals, but also to the achievement of the goals of the 
organisation itself (Fukuyama, 1995), as it influences the organisation's efficiency and provides future members of the organisation (e.g., students) with access to its social capital resources.

Research in the area of the sociology of education mostly relies on Coleman's conceptual framework (Dika \& Singh, 2002). In his own research (1986, 1987, 1988), Coleman primarily focused on researching the educational achievements of underprivileged students. This research focused on relationships between the family and the community through which it became possible to explain the higher educational achievements of students based on expected achievements with respect to their socioeconomic status (Miekiewicz et al., 2011). Hoffer's research (1986, according to Coleman, 1988) has shown that the drop-out rate of high-school students from families with both parents, a maximum of two children and high maternal expectations of the child (higher education) is $8.1 \%$. The school drop-out rate increases to $30.6 \%$ for students from one-parent families with four children and no maternal expectations that the child will enter higher education (Hoffer, 1986 according to Coleman, 1988). Coleman and Hoffer (1987) conducted research on differences between the educational achievements of students who attended public high schools (893 schools), catholic schools (84 schools) and other private schools (27). The drop-out rate between the second and final years of education were the smallest in catholic schools (3.4\%), followed by other private schools (11.7\%), while the highest rates were observed in public schools (Coleman \& Hoffer, 1987). The research showed that the educational achievements of students in catholic schools were not determined by their socioeconomic status or religious affiliation, but were significantly related to the characteristics of catholic schools, which nurture a feeling of community cohesion in which both adults and children are involved (Coleman \& Hoffer, 1987).

Coleman's concept of social capital became one of the most frequently used concepts in the area of social sciences, but it was also a target of fierce criticism. His arguments were considered tautological and circular: it seemed that social capital existed solely if it had a positive effect on outcomes on the community level. Consequences and causes are not adequately differentiated (Durlauf 1999). Some authors (e.g., Rose 2000) have attempted to establish a causal relationship, but these results, too, are far from conclusive. The aforementioned circularity also relates to Coleman's failure to offer any systematic explanation of the differences between the agent's desire for commitment (to enter into a relationship) and his/her ability to do so (Portes, 1998). Instead, inequalities in achievements, which are present at every level of the social structure, are ascribed to structural dysfunctions such as the relative limitation of 
network (relationship) closure and its consequences: the lack of norms produced by social capital. Adler and Kwon (2002) state that network closure is not indispensable for the functioning of social capital, while Lin (2001) claims that network closure should be insisted on only when achieving the specified aims of an individual. When individuals aspire to maintaining/preserving specific social relationships, closing the network is relevant; however, when agents seek and aspire to obtain resources of social capital, they require relationships with other agents, in which case closing the network is not relevant. Burt (1992) concluded that a lean network with few excessive ties often provides greater social capital benefits. Network closure can negatively influence external efficiency: it can result in distrust outside the group (Fukuyama, 2001). Moreover, Portes (1998) points out that Coleman does not take into consideration the existence of negative social capital, which can be manifested in the norms and relationships of particular clans whose activities are illegal. Foley and Edwards (1999) reviewed 45 recent articles reporting empirical research employing the concept of social capital and concluded that social capital depends on the social context making such capital specific with respect to context. Given that social capital is context dependent, social resources are not justly and evenly distributed, which is something Coleman fails to address. Shucksmith (2000) rejects the notion that social capital is a common benefit and claims that viewing social capital as a common benefit conceals inherent social inequalities, as resources are approached and possessed depending on the social and cultural capital that we already possess.

Coleman's critics above all resent his neglect of the differences in the social (i.e., status) positions of an individual. However, in Coleman's studies, particularly is his report of 1966 , the role of socioeconomic status in an individual's education is not denied; in fact, it is emphasised. Israel, Beaulieu and Hartless, (2001), who follow Coleman's example of the conceptualisation of social capital, point out that a higher level of parental education and higher economic capital of a family contribute to better educational achievements. We conclude that, although supporters of Coleman's approach do not ignore social inequalities in their research, they do not have a handhold in Coleman's theory to explain the differences in educational achievements that arise due to social differences, i.e., differences in socioeconomic status. However, Coleman's followers do recognise the enormous power of social capital in cases where individuals of the same socioeconomic status display different educational achievements: those with richer social capital demonstrate better educational achievements (Adedokun, 2007; Khattab, 2003). Khattab (2003), for example, concludes that, despite being an underprivileged minority with lower socioeconomic status in 
Israeli society, Palestine students have high educational aspirations largely as a result of possessing high social capital. Research of this type manages to justify the characteristics of the theory of rational actions (Dyk \& Wilson, 1999; Lopez, 1996; Smith, Beaulieu \& Israel, 1992; White \& Glick, 2000).

There is, however, research with contrary findings. For instance, research by McNeal (1999) established that social capital within a family (parental involvement in a child's education) is positively related to behaviour and educational achievements of traditionally privileged high-school students, while the relationship between social capital and educational achievements as well as behaviour in children with lower socioeconomic status was significantly smaller. McNeal's findings (1999) could be a result of the quality of parental engagement (parents with a higher education have a more efficient approach in terms of education) or of school employees treating children with lower socioeconomic status differently; neither explanation, however, supports concepts from the theory of rational action. Furthermore, in the aforementioned research (McNeal, 1999), parental and teacher interaction did not prove to be significant for educational achievements and student behaviour.

A far greater number of studies relying on Coleman's concept of social capital have, however, confirmed the role of social capital in establishing social mobility (Lopez, 1996; Morgan \& Sørenson, 1999; Sun, 1998; Sun, 1999 according to the research review, Dika, 2003). Dika \& Singh (2002) report that Coleman's concept of social capital was investigated using quantitative analysis and nationally representative samples by the majority of researchers (e.g., Dyk \& Wilson, 1999; Hofferth, Boisjoly \& Duncan, 1998; Lopez, 1996; Morrow, 2001; Muller, 2001; Muller \& Ellison, 2001; Parcel \& Dufur, 2001; Yan, 1999 according to research review, Dika \& Singh, 2002). This is confirmed by the fact that Coleman himself, along with his associates (1966), published one of the most comprehensive statistical reports on the influence of social capital on high-school education, which is based on a nationally representative sample (NELS). However, a far smaller number of studies (e.g., Bianchi \& Robinson, 1997; Fritche; 1999; Kahne \& Bailey, 1999; Laureu \& Horvat, 1999 according to the research review by Dika \& Singh, 2002) of a qualitative type and following Coleman's example actually investigated the relationship between social capital and the educational achievements of an individual. Nonetheless, over the past decade, such studies have become more frequent (e.g., Harper \& Griffin, 2011; Palmer \& Dancy, 2008; Palmer \& Gasman, 2008; Richardson, 2009) and largely confirm positive relationships between social capital and educational achievements. 


\section{Bourdieu's concept of social capital}

For Bourdieu (1986), social capital is the aggregate of current or potential resources related to existing, permanent networks, which can be based, to a greater or lesser extent, on institutionalised relationships of interpersonal respect and acceptance. An individual can use relationships with other individuals in order to achieve a goal, e.g., an educational goal. Bourdieu's analysis of social capital and its influence on educational achievements cannot be understood without his broader theory of capitals (which encompasses cultural and economic capital) as well as the concept of field and habitus. In Bourdieu's theory, the foundation of all capitals is economic capital, as a cause and consequence of possessing social and cultural capital. Bourdieu also claims that possession of and access to capitals is unevenly distributed in society (Bourdieu, 1986). His theory of social reproduction, which centres on economic and symbolic (cultural and social) capital, holds that the actions of an individual are largely determined by external factors, i.e., socioeconomic status. This theory is therefore far more pessimistic in character than that of Coleman, where the power of the individual and his/her action is significantly conditioned by social factors, and social capital mostly serves in the transfer of cultural and economic capital from generation to generation, thus contributing to the reproduction of the existing social order. As for Bourdieu's concepts of fields and habitus, they are, with some distinctions, most similar to Goffman's dramaturgical theory (1959), in which the field is represented by a play area (stage) where the battle between agents takes place: between dominant and subordinate, founded on the common, tacit acceptance of the interests characteristic of each field, e.g., academic interests. In defining habitus, Bourdieu states that it is: “... society embedded in a body, a biological individual ..." (Bourdieu, 1990, p. 63). Individuals of varied habitus (internal representations of an individual and his/her social background) engage in various battles on different fields. Such concepts provide an explanation not only of the vertical but also of the horizontal differences between individuals, and therefore their differences in the possession of social capital. However, a large number of the studies that have followed Bourdieu's approach include various forms of capital in their studies while overlooking the concepts of habitus and field, which could account for horizontal differences in the educational achievements of an individual (e.g., Fan, 2014; Hou, Li \& Zheng, 2008). In the desire to prove his theory, Bourdieu also conducted empirical research $(1984,1988,1990)$ by which he justified his analytical instrument. Authors who follow Bourdieu's tradition research social capital that is available to an individual outside the family (rooted in relationships with 
friends, acquaintances, parents' school and business connections) and use Bourdieu's theory of social-cultural reproduction to explain ways in which social capital acts to serve the reproduction of social inequalities (e.g., Ra, 2011).

There is a difference between Bourdieu's and Coleman's conceptualisation of social capital. Coleman's concept of social capital encompasses the quality of relationship/association within the family and beyond the family. Unlike Coleman, Bourdieu sees quality relationships within the family (e.g., the support and participation of parents in common activities with children/ students) as cultural capital and does not place them in social capital. According to Bourdieu, social capital encompasses the totality of resources that stem from belonging to groups beyond the family, enabling all members to use the collective capital. The difference between Bourdieu and Coleman is further evident in that Bourdieu finds the level of parental education to be an aspect of cultural capital, while Coleman sees it as a measure of the human capital of the family. Furthermore, when referring to the family as cultural capital, Bourdieu does not take into consideration the family's structure (presence of both parents, number of siblings, etc.), while this is included in Coleman's concept of social capital. Nor does Bourdieu's approach to social capital include the social networks that are accessible to individuals as members of particular organisations (schools, colleges). However, the qualitative and quantitative aspects of relationships in particular organisations are, according to Bourdieu, encompassed in the concept of institutional habitus (Bourdieu \& Passeron, 1990). Institutional habitus reflects the roles of an organisation's members, as well as the institutionalised rules that create a common cognitive system (Khanchel \& Ben Kahla, 2013) and represents the link between an individual's behaviour and the social structure (Emirbayer \& Johnson, 2008). In her research, Doolan (2009) included the number of students in a particular programme of study and the communication of students with teachers as aspects of institutional habitus, which Coleman would refer to as aspects of the college's social capital. Followers of Bourdieu's approach imply a broad spectrum of variables under the notion of institutional habitus, as it includes the internal and external world of the individual, the objective and subjective aspects (Myers, 2005). Some authors find Bourdieu's concept of habitus (including institutional habitus) to be complex and ambiguous, which accounts for it being difficult to implement (Sulivan, 2002). The concept of habitus has been used within the framework of ethnographic studies (Horvat \& Antonio, 1999; Reay et al., 2001), showing a significant relationship with educational achievements, which points to the relevance of its development and use in research in the area of education. Furthermore, Bourdieu claims that relationships between people do not differ only 
in quality and quantity, but that their specificities are reflected in the extent of a person's possession of cultural and economic capital within a network of acquaintances. In other words, the individual's network of acquaintances need not be very broad but may include richer and more notable people, resulting in the resources of social capital at the individual's disposal being more efficient. For this individual, social institutions, such as schools and colleges, contribute to the creation of social inequality, as they support the culture of the dominant class by helping it to convert its cultural capital into wealth (Haralambos \& Holborn, 2002).

Bourdieu's theory focuses more on the socioeconomic status and cultural capital of an individual in attaining educational achievements than on his/ her social capital; the latter is therefore much less elaborated in Bourdieu's work than in that of Coleman. What stands in favour of Bourdieu is the fact that economic capital is significantly and positively related to educational achievements (Baranović, Jugović \& Puzić, 2013; Bidwell \& Friedkin, 1988; Portes, FernándezKelly \& Haller, 2009; Puzić, Doolan \& Dolenec, 2006). Authors who follow Bourdieu's approach claim that differences in the possession of social capital by an individual are a result of differences in possessing economic capital (e.g., Bruen, 2014); however, very little research has managed to confirm the notion that social capital is a mechanism through which social inequalities are reproduced (Tzanakis, 2011). Doolan (2009) concluded that certain aspects of social capital (e.g., parents' friends) play a role in supporting social mobility, which is not characteristic of the theory of socio-cultural reproduction. Bruen (2014) established that aspects of social capital include resources whose use enables the social mobility of students. Douglas Martin (2010) also states that particular forms of cultural and social capital are available to all regardless of social status. Furthermore, research has been unable to establish the support of members of a dominant class through the inadvertent and conscious behaviour of teachers as agents (Goldthorpe, 2007). Goldthorpe (2007) points to the existence of differences between the source ("wild") and modified ("tamed") approach to Bourdieu, where the former is a follower of Bourdieu's original standpoint and the latter encompasses various modifications of his theoretical foundation. On the most part, empirical studies have not supported the approach based on Bourdieu's source conceptualisation (Tzanakis, 2011); however, they have managed to support the modified approach to using Bourdieu's theory, whose authors acknowledge the role of social capital in enabling social mobility, thus distancing themselves from Bourdieu's original theoretical model. 


\section{An integrative approach}

Despite the numerous studies that combine Coleman's and Bourdieu's approach in the use of social capital (e.g., Pishghadam \& Zabihi, 2011) and in discussion of research results, only a small number of researchers explicitly state that they have implemented this approach. There are few authors (e.g., Ho, 2003) in the area of the sociology of education who state that they have actually combined Bourdieu's and Coleman's approach in their research. Authors who combine Coleman and Bourdieu actually create their own theoretical and methodological concepts for questioning the relationship between social capital and educational achievements. For example, Pishghadam and Zabihi (2011) investigate social capital available within the family and beyond the family, as well as researching the family's structure; however, the social capital of the family also encompasses cultural capital in Bourdieu's sense (involvement in cultural practices and possession of cultural goods), while the level of parents' education is isolated as a separate variable. Nonetheless, relevant literature (e.g., Pusztai, 2014) often poses the question as to whether it is justified to integrate such concepts, considering they have emerged on entirely divergent foundations: Bourdieu's theoretical approach serves to explain social inequality and is close to Marxist theory, whereas Coleman's approach emphasises individual potentials and is close to Durkheim's theoretical roots. We are of the opinion that Bourdieu's and Coleman's concepts can, in fact, be integrated, as they involve complementary definitions of social capital, but the implementation should be handled in a manner that involves all of the key parameters of both Bourdieu and Coleman, with adequate distinction. For example, social capital can be implemented in a way that includes relationships within the family, the community and educational institutions, as well as relationships with friends, parents' friends, etc. In this way, Coleman's aspects of social capital are combined with those of Bourdieu. The theoretical and methodological justification for such approaches already exists, as authors using an integrated approach have established their approaches so as to overcome the shortcomings of both Coleman's and Bourdieu's models (Burt; 1997; Lin, 2001).

Following this line of thought, a network approach to researching social capital is presently being developed. One of the most frequent forms of network analysis in network approaches is the model of ego-network, which stems from the individual agent in the system, regardless of whether it involves an individual, family or company (Babović, 2005). A chain method reveals all of the agents with which the starting agent has direct relationships, as well as the relationships between these agents. Taking a structural approach, it is assumed 
that agents within a network do not behave according to personal attitudes, norms and individual characteristics, but according to their position within the network structure. This allows for an analysis of horizontal and vertical differences in possessing the social capital and social resources that are available to an individual within particular organisations, as well as beyond these organisations. Furthermore, the merging of Coleman's and Bourdieu's theories is far more frequent when researching social capital as a characteristic of institutions; for example, in researching an organisation's efficiency (Svendsen \& Svendsen, 2004; Tierney, 2006). Tierney's (2006) social capital of an organisation is viewed through Coleman's concept of social capital, which consists of all of the internal relationships possessed by a particular group (including common norms and values). It also encompasses relationships beyond the organisation (more common to Bourdieu's understanding of social capital, which is not related to the norms and values of a group) and relates them to an individual's achievements in an organisation and the efficiency of the entire organisation. Analogous to this, the social capital of educational institutions and their influence on the educational achievements of an individual can be viewed from the same perspective.

\section{Conclusion}

By examining Bourdieu's and Coleman's approaches in researching relationships between social capital and educational achievements, it can be concluded that both approaches have advantages while also demonstrating serious limitations (Tzanaki, 2013). Coleman is primarily criticised on account of his theory failing to explain differences in the possession of social capital by individuals of different social backgrounds. However, it has proven to be rather efficient in explaining differences between individuals of a similar social background. Thus, the theory of rational action, whose fundamental conceptual means is social capital, functions successfully when homogenous groups of sample participants are in question (homogenous with respect to socioeconomic status). For example, if the relationship between social capital and enrolment of students in private and public universities is being researched, it is likely that the economic and cultural capital of the parents will play a more significant role than social capital. However, if we are investigating the educational achievements of students who are studying fee-free in a particular programme (e.g., teacher education), it is more likely that the differences in educational achievements will, for the most part, depend on the possession of social capital. In terms of advantages, Coleman's theory of social capital is successfully 
implemented in the majority of quantitative research; thus, its validity could be tested without including ethnographic studies. Moreover, Coleman's approach enables an analysis of relationships within the family, away from the family and in particular social institutions (communities, organisations) under one concept, i.e., the concept of social capital, which further simplifies the conceptualisation and execution of research based on this approach.

On the other hand, Bourdieu's original theory is much broader and more elaborated, which is both an advantage and a drawback. The majority of quantitative studies founded on Bourdieu's conceptualisation of social capital have not consistently and unambiguously supported the theory of social reproduction (Tzanakis, 2011). Furthermore, empirical research has shown that it is rather difficult to clearly operationalise the concepts of habitus and field, which are very important for the research and understanding of the relationship between social capital and educational achievements. Accordingly, when Bourdieu's theory of sociocultural reproduction is tested in the area of education, the use of mixed research methods, both qualitative and quantitative, is recommended. The theory itself is more suitable for explaining differences in the educational achievements of individuals in highly differentiated societies (Grossman, 2013), or in cases where there are discernible differences in socioeconomic and socio-cultural status of the participants in the sample. Critics of Bourdieu reject his theory, as it is not supported by numerous studies, particularly quantitative research. Moreover, Bourdieu's standpoints are considered outdated, while his concepts prove to be useless in research on educational achievements. The significance of his theory is only acknowledged in the theoretical explanations of empirical results, particularly when discussing habitus and field (Sullivan, 2002). Coleman's theory is also subject to criticism. It is said to be overly optimistic (Tzanakis, 2013). However, the fact that research results do not always confirm the basic premises of the theoretical perspectives does not mean that the concepts, theory and methodology proposed by Coleman and Bourdieu are epistemologically questionable. Quite the opposite: research showing that social capital is a means of social mobility proves that the theory of rational actions functions, regardless of the fact that such findings are the result of research based on Bourdieu's conceptual foundation, whose starting point is a different theoretical approach, i.e., the theory of social reproduction. A similar situation occurs with research using Coleman's conceptual framework of the theory of rational action (including social mobility), which can prove that social inequalities are reproduced.

In addition to these cases, there are studies that simultaneously confirm the activity of both Bourdieu's and Coleman's theories (Ho, 2013). Ho (2013) 
explains the relevance of self-respect in children and its role in attaining educational success. In so doing, she emphasises how research results indicate that economic and cultural capital are significantly related to children's self-respect, i.e., educational achievements, leading to the conclusion that social background is a precondition for educational achievements and thus enables social reproduction. However, social capital (measured according to the degree of parental involvement in a child's education) shows a stronger relationship between selfrespect and educational achievements, making the quality of the parent-child relationship responsible for social mobility, as its influence on education is far stronger than the influence of other capital. As such, research indicates that particular capital promotes the reproduction of social inequalities, while other capital promotes social mobility.

It can be said that Coleman's and Bourdieu's theoretical approaches and concepts that serve research of the relationship between social capital and educational achievements have not been discredited, as they are very successfully used in numerous current studies. It seems justifiable to use Coleman's and Bourdieu's concepts either independently or in combination. In so doing, it is quite logical that various uses of social capital result in various research results. For example, in testing the empirical model of social capital of Bourdieu and Coleman on the same sample (3,00o participants), Grossman (2013) concluded that both models are valid. He also established that the level of possession of social capital operationalised according to Coleman does not differentiate between social layers and ethnic groups, but differs with respect to racial belonging, while Bourdieu's model indicates differences in social capital between individuals of different class, race and ethnic affiliation. On the other hand, even differently operationalised concepts of social capital can lead to similar results. For example, social capital operationalised in research according to Bourdieu's concept can be positively related to social mobility, as is evident in research of social capital relying on Coleman's concept of social capital. Vice versa, research on social capital operationalised according to Coleman indicates that social capital can function as a means of social reproduction of society, which is in accordance with Bourdieu's approach. In discussing research that combines both Bourdieu's and Coleman's approach, it is evident that its limitations lie in an insufficient elaboration of the theory on which the integration is founded. In research to date, this integration has consisted of fragments of the theoretical perspectives of both Coleman and Bourdieu. In this context, it is crucial to mention that alternative approaches aiming to overcome the limitations of both theories are being developed, such as the network approach to researching social capital. 
The present overview could therefore contribute to the establishment of a theoretical context for the empirical scrutiny and explanation of the impact of social capital on the educational achievements of individuals.

\section{References}

Acar, E. (2011). Effects of social capital on academic success: A narrative synthesis. Educational Research and Reviews, 6(6), 456-461.

Adedokun, O. A. (2007). Social capital and rural adolescents' educational achievements an aspiration. Doctoral thesis. West Lafayette: Purdue University.

Adler, P. S., \& Kwon, S. (2002). Social capital: prospects for a new concept. The Academy of Management Review, 27(1), 17-40.

Babović M. (2005). Socijalne mreže - povezivanje društvenih aktera u sferi ekonomskih aktivnosti.

Sociologija, 27(4), 351-371.

Baranović, B., Jugović, I. \& Puzić, S. (2014). Važnost obiteljskog podrijetla i roda za uspjeh iz matematike i odabir srednje škole. Revija za socijalnu politiku, 21(3), 285-307.

Bidwell, Ch. E., \& Friedkin, N. E. (1988). The Sociology of Education. In N. En. Smelser (Ed.),

Handbook of Sociology (pp. 449-471). London: Sage.

Baron, S., Field, J., \& Schuller, T. (2000). Social Capital: Critical Perspectives. Oxford: Oxford University Press.

Bourdieu, P. (1977). Outline of a theory of practice. Cambridge: Cambridge University Press.

Bourdieu, P. (1984). Distinction: A social critique of the judgment of taste. Cambridge, Mass.: Harvard University Press.

Bourdieu, P. (1986). The Forms of Capital. In J. Richardson (Ed.), Handbook of theory and research for the sociology of education (pp. 241-258). New York: Greenwood.

Bourdieu, Pierre (1988). Homo Academicus. Stanford: Stanford University Press.

Bourdieu, P. (1990). In other words: essays towards a reflexive sociology. Stanford: Stanford University Press.

Bourdieu, P., \& Passeron, J. C. (1990). Reproduction in education, society and culture. Sage, London.

Bruen, T. (2014). Mature students' narratives of Irish higher education: A critical bourdieusian analysis. Doctoral thesis. Sheffield: University of Sheffield.

Burt, R. S. (1992). Structural holes: The social structure of competition. Cambridge, Mass: Harvard University Press.

Burt, R. S. (1997). Contingent value of social capital. Administrative Science Quarterly, 42(2), 339-365. Coleman, J. S. (1988). Social capital in the creation of human capital. The American Journal of Sociology, 94(1) Supplement: Organizations and institutions: Sociological and economic approaches to the analysis of social structure, 95-120.

Coleman, J. S. (1990). The Foundations of Social Theory. Cambridge, Mass: Harvard University Press. Coleman, J. S., \& Fararo, T. J. (1992). Rational choice theory: Advocacy and critique. Newbury Park: 
Sage Publications.

Coleman, J. S. (1993). Rational reconstruction of society. American Sociological Review, 58 (1), 1-15.

Coleman, J. S., \& Hoffer, T. (1987). Public and Private High Schools: The Impact of Communities. New York: Basic Books.

Coleman, J., Campbell, E., Hobson, C., McPartland, J., Mood, A. et al. (1966). Equality of Educational Opportunity. Washington, D.C.: U.S. Office of Education.

Coleman, J., Hoffer, T. \& Kilgore, S. (1982). High School Achievements: Public, Catholic and Private Schools Compared, New York: Basic books.

Durlauf, S. (1999). The case "against” social capital focus. Newsletter for the Institute for Research on Poverty, 20(3), 1-5.

Dika, S. L., \& Singh, K. (2002). Applications of social capital in educational literature: A critical synthesis. Review of Educational Research, 72(1), 31-6o.

Dika, S. L. (2003). The effects of self-processes and social capital on the educational outcomes of high school students. Doctoral thesis. Blacksburg, VA: Virginia Polytechnic Institute and State University. Doolan, K. (2009). My Dad Studied Here Too: Social Inequalities and Educational (dis)Advantage in a Croatian Higher Education Setting. Doctoral thesis. Cambridge: Darwin College, Cambridge University.

Douglas Martin (2010). Social class and elite university education: a Bourdieusian analysis. Doctoral thesis. Durham: Duke University.

Dyk, P. H., \& Wilson, S. M. (1999). Family-based social capital considerations as predictors of attainments among Appalachian youth. Sociological Inquiry, 69(3), 477-503.

Emirbayer, M., \& Johnson, V. (2008). Bourdieu and organizational analysis. Theory and Society.37(3), 1-44.

Eng, S. (2009). Social capital and academic achievements among children in Cambodia: A close look at family. Doctoral thesis. Texas: Texas Tech University.

Erickson, B. H. (1996). Culture, class, and connections. American Journal of Sociology, 102(27), 217-51. Fan, J. (2014). The impact of economic capital, social capital and cultural capital: Chinese families' access to educational resources. Sociology Mind, 4(4), 272-281.

Flap, H. D. (1991). Social capital in the reproduction of inequality. Comparative Sociology of Family, Health and Education, 20(6), 6179-6202.

Foley, M. W., \& Edwards, B. (1999). Is it time to disinvest in social capital? Journal of Public Policy, 19(1), 141-173.

Fukuyama, F. (1995). Trust: Social virtues and the creation of prosperity. New York: Free Press.

Fukuyama, F. (2001). Social capital, civil society and development, Third World Quarterly, 22(1), 7-20. Goffman, E. (1959). The presentation of self in everyday life. New York: Anchor Books.

Goldthorpe, J. (2007). Cultural capital: Some critical observations, Sociologica, 2(1), 1-23.

Golubović N., \& Golubović S. (2007). Alternativni pristupi konceptualizaciji društvenog kapitala,

Ekonomski anali, 1, 174-175.

Grossman, E. (2013). An examination of Putnam's, Coleman's, and Bourdieu's conceptualizations 
of social capital and the structural differences across class, race, and gender groups. Doctoral thesis. Akron: The Graduate Faculty, University of Akron.

Haralambos, M., \& Holborn M. (2002). Sociologija: teme i perspektive. Zagreb: Golden marketing. Harper, S. R., \& Griffin, K. A. (2011). Opportunity beyond affirmative action: How low-income and working-class black male achievers access highly selective, high-cost colleges and universities. Harvard Journal of African American Public Policy, 17(1), 43-6o.

Ho, S. C. (2003). Home School Collaboration and Creation of Social Capital. Hong Kong Journal of Sociology 4(1), 57-85.

Hou, L., Li, F., \& Zheng, Q. (2008). The impact of family background on the access to quantity and quality of higher education-from social stratification perspective. Journal of Higher Education, 29(10), 39-45.

Hofferth, S., Boisjoly, J., \& Duncan, G. (1998). Parents' extrafamilial resources and children's school attainment. Sociology of Education, 71(3), 246-248.

Horvat, E. M., \& Antonio, A. L. (1999). Hey, those shoes are out of uniform: African American girls in an elite high school and the Importance of habitus. Anthropology \& Education Quarterly, $30(3)$, 317-342.

Israel, G. D., Beaulieu L. J., \& Hartless, G. (2001). The influence of family and community social capital on educational achievements. Rural Sociology, 66(1), 43-68

Khanchel, H., \& Ben Kahla, K. (2013). Mobilizing Bourdieu's theory in organizational research. Review of General Management, 17(1), 86-94.

Khattab, N. (2003). Explaining educational aspirations of minority students: the role of social capital and students' perceptions. Social Psychology of Education, 6(4), 283-302.

Lin, N. (1999). Building a network theory of social capital, Connections, 22(1), 28-51.

Lin, N. (2001). Social Capital: A theory of social structure and action. New York: Cambridge University Press.

Lopez, E. (1996). Social capital and the educational performance of Latino and Non Latino youth. San Luis Obispo, CA: Julian Samora Research Institute.

Loury, G. (1977). A dynamic theory of racial income differences. In P. Wallace, A. LaMond, (Eds.), Women, Minorities, and Employment Discrimination (pp. 153-188). Michigan: Lexington Books.

McNeal, R. B. J. (1999). Parental involvement as social capital: Differential effectiveness on science achievements, truancy, and dropping out. Social Forces, 78(1), 117-144.

Mikiewicz, P., Torfi, J., Gudmundsson, J. G., Blondal, K. S., \& Korczewska, D. M. (2011). Social capital and education: Comparative research between Poland and Iceland, final report. Wroclaw: University of Lower Silesia.

Myers, K. (2005). Racetalk: Racism hiding in plain sight. Maryland: Rowman and Lettlefield

Publishing group.

Palmer, R. T., \& Dancy, T. E., II. (2008). Shaping success among Black males in an HBCU: study of barriers and benefits. Georgia Journal of College Student Affairs, 22(1), 59-22.

Palmer, R. T., \& Gasman, M. (2008). It takes a village to raise a child: the role of social capital in 
promoting academic success for African American men at a black college. Journal of College Student Development, 49(1), 52-70.

Parcel, T. L., \& Dufur, M. (2001). Capital at home and at school: Effects on child social adjustment. Journal of Marriage and Family, 63(1), 32-47.

Pishghadam, R., \& Zabihi, R. (2011). Parental education and social and cultural capital in academic achievements. International Journal of English Linguistics, 1(2), 50-57.

Pusztai, G. (2014). The effects of institutional social capital on students' success in higher education. Hungarian Educational Research Journal, 4(3), 60-73.

Portes, A., (1998). Social capital: its origins and applications in modern sociology. Annual Review of Sociology, 24(1), 1-24.

Portes, A., Fernandez-Kelly, P., \& Haller W. (2009). The adaptation of the immigrant second generation in America: A theoretical overview and recent evidence. Journal of Ethnic and Migration Studies, 35(7), 1077-1104.

Putnam, R. D. (1993). The prosperous community. The American Prospect, 4(13), 35-42.

Puzić, S., Doolan, K., \& Dolenec, D. (2006). Socijalna dimenzija “Bolonjskog procesa” i (ne) jednakost šansi visokog obrazovanja: neka hrvatska iskustva. Sociologija sela, 44(2-3), 221-243. $\mathrm{Ra}, \mathrm{E}$. (2011). Understanding the role of economic, cultural, and social capital and habitus in student college choice: An investigation of student, family, and school contexts. Doctoral thesis. Michigan: School of Education, University of Michigan.

Reay, D., David, M. E., \& Ball, S. (2005). Degrees of Choice: social class, race and gender in higher education. Stoke-on-Trent: Trentham Books.

Richardson, J. B., Jr. (2009). Men do matter: Ethnographic insights on the socially supportive role of the African American uncle in the lives of inner-city African American male youth. Journal of Family Issues, 3o(8), 1041-1069.

Rose, R. (2000). How much does social capital add to individual health? A survey study of Russians, Social Science and Medicine, 51(9), 1421-1435

Shucksmith, M. (2000). Endogenous development, social capital and social inclusion perspectives from leader in the UK. Sociologia Ruralis, 40(2), 208-218.

Schuller, T., Baron, S., \& Field, J. (2000). Social capital: A review and critique, In S. Baron, J. Field and T. Schuller (Eds.), Social capital: Critical perspectives (pp. 1-38), Oxford: Oxford University Press. Smith, M. H., Beaulieu, L. J., \& Israel, G. D. (1992). Effects of human capital and social capital on dropping out of high school in the South. Journal of Research in Rural Education, 8(1), 75-87. Schaefer-McDaniel, N.J. (2004). Conceptualizing social capital among young people: Toward a new theory. Children, Youth and Environments, 14(1), 140-150.

Sullivan, A. (2001). Cultural capital and educational attainment. Sociology, 35(4), 893-912. Sullivan (2002). Bourdieu and education: how useful is Bourdieu's theory for researchers? The Netherlands 'Journal of Social Sciences, 38(2), 144-166.

Sun, Y. (1999). The contextual effects of community social capital on academic performance. Social sciences Research, 28(4), 403-426. 
Svendsen, G. L. H. \& Svendsen, G. T. (2004). The creation and destruction of social capital: Entrepreneurship, co-operative movements, and institutions. Cheltenham, UK: Edward Elgar. Tierney, W. G. (2006). Trust and the public good: Examining the cultural conditions of academic work. New York: Peter Lang Publishing.

Tzanakis, M. (2011). Bourdieu's social reproduction thesis and the role of cultural capital in educational attainment: A critical review of key empirical studies. Educate, 11(1), 76-9o.

Tzanakis, M. (2013). Social capital in Bourdieu's, Coleman's and Putnam's theory: empirical evidence and emergent measurement issues. Educate, 13(2), 2-23.

Winter, I. (2000). Towards a theorised understanding of family life and social capital. Working Paper No. 21. Melbourne: Australian Institute of Family Studies.

Woolcock, M. (1998). Social capital and economic development: toward a theoretical synthesis and policy framework. Theory and Society, 27(2), 151-208.

Yan, W. (1999). Successful African American students: The role of parental involvement. J. Negro Education, 68(1), 5-22.

\section{Biographical note}

Silvia Rogošıć completed the Study of Croatian Culture and Sociology at the Centre for Croatian Studies, University of Zagreb. In 2016, she received her Ph.D. from the Faculty of Teacher Education in Zagreb with the thesis in sociology of education. She works as postdoctoral assistant at the Department of Teacher Education Studies (Chair of Philosophy and Sociology) at the Faculty of Teacher Education in Zagreb. Since 2010 she has been lecturing in sociology of education at the same faculty. She has published numerous articles and participated in two research projects as a team member.

BRANislava BARANOvić is currently working as a Senior Scientific Associate at the Institute for Social Research in Zagreb and as the Director of the Institute. She is one of the founders of the Centre for Educational Research and Development, a scientific unit within the Institute, and she was its director for 10 years. She is also teaching Sociology of education at graduate level at the Faculty of Teacher Education, University of Zagreb. Her main fields of interest are the sociology of education, national curriculum development, social inequalities in education, and gender and education. She has written and edited 6 books, and published numerous articles and participated in 20 research projects as a project leader and team member. 